\title{
The Importance Of Introducing Oral Tradition To Sentani Children, Jayapura
}

\author{
Wigati Yektiningtyas ${ }^{1}$, Mesabia Pramudhita Modouw ${ }^{2}$ \\ Universitas Cenderawasih; Jayapura ${ }^{1}$, Universitas Gadjah Mada, Yogyakarta ${ }^{2}$ \\ \{wigati_y@yahoo.com ${ }^{1}$, sashamodouw@gmail.com ${ }^{2}$ \}
}

\begin{abstract}
Sentani tribe in Jayapura, Papua has various oral tradition, i.e. folktales, oral poems, traditional proverbs, folksongs, dances, painting, traditional architecture, etc. Unfortunately, Sentani children as the future generation who will continue the existence of the socio-cultural life of Sentani people do not recognize their ancestor's cultural heritages. This paper aims at discussing the importance of introducing oral tradition that focuses on folktales and folksongs to Sentani children since those two works are related, simpler, and accompanied by musical instruments (for folklsongs). Data of folktales and folklsongs were collected from some informants, i.e. tribal chiefs and Sentani elders in Waena, Ayapo, and Hobong in June-September 2019. The term "children" belongs to those children who are in 4- 8 years old or those who are in Early Childhood Education and grades 1-3 of Primary Schools. This research adopted socio-cultural approach. From the discussion, it is found that (1) folktales and folksongs could be used as media of learning Sentani language, traditional knowledge, and moral values, (2) the learning was a breakthrough of disseminating the Sentani cultural heritages and various socio-cultural values embedded, and (3) the learning was a strategy of Sentani cultural heritages preservation.
\end{abstract}

Keywords: Sentani children; oral tradition; folktales; folksongs; preservation.

\section{Introduction}

Sentani tribe in Jayapura is blessed with rich oral tradition that flourished in the past: folktales, oral poems, traditional proverbs, folksongs, dances, painting, carving, traditional architecture, traditional religion, etc. The oral tradition is used by the old Sentani community as a medium to convey traditional knowledge, history, education, and even social-moral messages as their life's principle (Yektiningtyas, 2019: 106; John Modouw and Corry Ohee, 2018-personal communication/pers.com.). According to Danandjaja (2002), oral tradition is a part of folklore which is categorized into verbal folklore, for example folktales, oral poems, traditional proverbs, folksongs, etc.; partial-verbal folklore, for example traditional beliefs, games, customs, etc.; and non-verbal folklore, for example traditional architecture, painting and carving, traditional medicine, etc. Ramses Ohee (90 years), the oldest Sentani ondofolo, the highest Sentani tribal chief (2020-pers.com.) said that the old Sentani people used oral 
traditions as a medium to strengthen family and social life. Folktales are told by parents to educate children and as bedtime stories for them. Ehabla, one of the popular oral poems sung by the community as media of commemorating the history of their clans and their lives. It was also used as a medium for reflection on rights and obligations, roles and social responsibilities, as well as to maintain good relations between them. Oral poem singing was usually done in the yard of $o b a e$, a traditional meeting house with typical Sentani architecture decorated with ohomo (carvings). Folksongs were sung in a social gathering of young people. Traditional proverbs were also used as a way to strengthen or break other people's conversations in both formal and informal communication. Sentani people used oral tradition as media of communication that strengthens their social relationship. This is also in line with Rahman's ideas about the roles of oral tradition as social communication (2017).

However, now many Sentani people, especially those who live in cities, do not recognize this oral tradition. Technology and modernization are often considered as the reasons for the loss of this oral tradition (c.f. Rahman, 2018; Yektiningtyas, 2019). Even more sad, Sentani children as the future generation who will continue the existence of the socio-cultural life of Sentani people do not recognize their ancestors' cultural heritages. They do not even speak Sentani anymore. Therefore, this paper discusses the importance of introducing this oral tradition to Sentani children so they can recognize it, love it, and practice it. If not, this cultural heritage will be lost together with all the philosophy, cosmology, local knowledge and moral values embedded in it. From the richness of Sentani oral tradition, folktales and folksongs are focused to be introduced to children because the two works are usually related, simpler, and interesting because they talk about life and surroundings. Folksongs are accompanied by musical instruments. The purpose of this paper is exploring (1) why is it important to introduce both Sentani folktales and folksongs to children? and (2) how to introduce those works?

\section{Methodology}

Data of folktales and folklsongs were collected from some informants, i.e. tribal chiefs and Sentani elders in Waena, Ayapo, and Hobong in June-September 2020 via close observation, interviews, transcription, and translation. From some data, there were three folktales, i.e. "Journey of Heram People to Yabansai", "The Sparrow and the Cassowary", as well as "Ebi and Kandei" and there were three folksongs, i.e. "Honong Yo", "Bokiki Fele-fele", and "Kandei Keija", used in this study. Both folktales and folksongs were chosen purposively related to the aims of the learning. Data of folktales were told in mixed language: Sentani and Indonesian while data of folksongs were obtained in Sentani language. They were then transcribed and translated into Indonesian. For this purpose, folktales were rewritten in both languages, Indonesian and Sentani using children language. FGD with tribal chiefs, Sentani elderly people, and parents was conducted to check the validity of data interpretation and translation. The materials were then tried out in Sekolah Adat Sentani, Hobong in November 2019. The term "children" belongs to those children who are in $4-8$ years of age or those who are in Early Childhood Education and grades 1-3 of Primary Schools. This research applied socio-cultural approaches since folktales and folksongs are closely related to the contextual background of Sentani socio-culture (Hesaraki, 2014; Lehtonen, 2020). 


\section{Discussion}

\subsection{The importance of introducing folktales and folksongs to children}

From long observation and research conducted in 2017-2018, Yektiningtyas concluded that Sentani children could not speak their local language and did not recognize their ancestral heritages. As the future generation who will continue the existence of Sentani people, they need special attention. Re(learning) Sentani ancestral heritages is not only for preservation and identity but how to motivate Sentani children to recognize, understand, and practice the language, philosophy, traditional knowledge and moral values in their life and pass them down to the coming generation. Compared to other works of oral tradition, folktales an folksongs are still circulated, use simpler language and accompanied by musical instruments (folksongs). The children also like to listen to folktales and sing some folksongs even though they do not know the meaning. By ultilizing what the children like, this research initiate to use both folktales and folksongs to remind them about their cultural heritages. This section higlights three important and basic things the children can learn from folktales and folksongs, i.e. (1) local language, (2) traditional knowledge, and (3) moral-spiritual values.

Since folktales and folksongs are told/written and sung in Sentani language, children can (re)learn their local language. In the research Yektiningtyas and Gultom (2018:228) found out the difficulties of Sentani children in leaning the language, i.e. (1) pronunciation, (2) SubjectObject-Predicate sentence structure (SOP/V), (3) tenses, (4) adposition, and (5) counting system. From this point, the learning can be directly focused on. For example, since the children are accustomed to speak Indonesian, they can use the vocabularies in folktales and folksongs to practice their pronunciation. Unlike Indonesian or English sentence structure that use Subject-Verb-Object (SVO), Sentani language uses Subject-Object-Verb (SOV) instead. This makes the learning harder and complicated. Simple folktales and folksongs due to repetition of reading/listening and singing can bridge the difficulties. For example, when they listen or sing some lines like "ebi najokho (his eyes) nekeunge bulele (got pecked)" (ebi's eyes were pecked), neyae (they) $f i$ (sago) anaikokhe (ate) (they ate sago), rukhe (fell down) nanoro (his wings) insekokhe (broke) (he fell down and broke his wings), the children learned Sentani sentence structure. When they were accustomed with the SOV structure, they hopefully will develop and practice more sentences. From a sentence "manggung mbai akhla nolo ne nekheye" (there is a cassowary in the jungle) (present tense) the children can convert into a past tense sentence "manggung mbai bure akhla nolo ne nekhewoye" (there was a cassowary in the jungle) or other tenses like present continous and present/past perfect tense. They can practice more post-position like akhlare (jungle to) (to the jungle), akhlara (the jungle from) (from the jungle), and akhlana (jungle in) (in the jungle). From "manggung mbai" (a cassowary), they can also develop mbai (one) to bhe (two), name (three), keli (four), mehembai (five/one hand), me hinim mbai (one hand plus one finger), me hinim bhe (one hand plus two fingers), me hinim name (one hand plus three fingers), me hinim keli (one hand plus four fingers), and me bhe (ten/two hands). Marthen Ohee, Maria Pepuho, and Ramses Ohee (2019-pers.com.) said that tenses and counting are the most complicated and frustrating learning for children. As parents and tribal chiefs they are also searching various effective ways in teaching local language.

Interestingly, from "Legend of Sentani Lake" and "Journey of Heram People to Yabansai", children learn about their origins, local knowledge of hunting, gardening, building houses, making canoes, natural conservation, and water management. This traditional knowledge have been ignored not only by children but by most of Sentani people. It is not easy to find Sentani people who are able to tell the process of gardening and making canoes of old Sentani 
people that were full of philosophy and moral teachings of keeping the balance of "three sacred relation", i.e. relation of people and gods $(H u)$, people and people, and people and nature (Yektiningtyas, 2019:110; Corry Ohee, 2019-pers.com). In daily life, those values are not practiced again. People prioritize their rights instead of their obligations. They also exploit nature for financial purposes. From "The Sparrow and the Cassowary", "Ebi and Kandei", "Bokiki Fele-fele", "Kandei Keija", the learners can learn some moral values, i.e. hardwork, cooperation, respect, care, and love. The following is the example of the importance of hardwork, cooperation and respect seen in "Journey of Heram People to Yabansai".

The Ondofolo's son was so sad, he felt that he was underestimated. Therefore he met the people and expressed his desire to leave the Honong area (now, East Sepik, PNG) and look for a new area. The community supported him and prepared all supplies and war equipment. There were many obstacles on the way, but with hard work and mutual cooperation they were able to overcome all obstacles and finally they arrived at Yabansai (now Sentani).

This expression is also supported in a famous Sentani folksong "Honong Yo" that sings about the heroism of ondofolo's son in leading the people by prioritizing hard work, mutual cooperation that resulted love and repect. In "The Sparrow and the Cassowary" that was suppotred by a song "Bokiki Fele-fele", it was told a sparrow who was considered small and weak but could defeat the arrogant and evil cassowary by using his strategy. Those moral teachings embedded in folktales and folksongs can be used as social awareness and media of children's character building to value hardwork, cooperation, honesty, discipline, love, and respect. In line with this, Irenius Pepuho and Origenes Monim (2019-pers.com.) also highlighted the importance of character building for Sentani children who are nowdays getting ignorant and individualistic.

\subsection{The introduction of folktales and folksongs to children}

In accordance with the children's millennial spirit, this study puts forward the introduction of folktales and folksongs in an interesting and creative way (c.f.Rahman, 2017; Utomo and Kurniawan, 2017:93). This is related to the expressions of Albert Pepuho, Anna Wally, and Corry Ohee (2019-pers.com.) that it is difficult to introduce Sentani language and culture to children even though they have tried to teach it at home. Therefore, folktales are taught through using picture books as well as big books in Sentani and Indonesian, games, drawing and coloring and singing to attract leaners' intention. The learning that was tried out at the Sentani Traditional School in Hobong in November 2019 received a positive response from the children.

In learning, vocabularies from folktales and folksongs were selected and classified into several themes, for example body parts, family members, home, natural environment, cultural objects, etc. which is complemented by ineresting pictures. Children were also asked to make phrases and sentences using the vocabulary they had learned. For example, from the word "ana" (mother"), children could make a phrase "ana foi" (good mother) and a sentence "ana foi emfeu anekho" (a good mother ate banana). From "imae" (house), the children made a phrase "imae kabham" (a big house), and a sentence "reyae imae kabhamre" (I go to the big house). Since the words are accompanied by pictures, the children were asked to color the picture. The process of coloring can help the children to internalize what they have learned. The vocabularies that have been learned by the children are reinforced by folktales reading by the teacher and folksongs singing at the same theme. At the end of the lesson, the teachers revealed the traditional knowledge of old Sentani people found in folktales and folksongs, for example how to make garden, build houses, build canoes, etc., as well as moral teachings. 
Then, a discussion was held where the children' gave responses about the cultural heritage and language of their ancestors.

To help the children in learning, video and audio learning were created, i.e. Sentani folktales telling, counting in Sentani language (number 1-10), introducing Sentani nature and environment, and folksongs sung by the children. This learning can be done at home, helped by the parents. As the first and important education institution, parents ideally help the children in introducing and teaching local language and cultural heritages (Yektiningtyas and Morin, 2020:120). The combination of learning at school and at home is regarded as good strategy in supporting the children in learning Sentani language and cultural heritages.

\section{Conclusion}

Folktales and folksongs are parts of Sentani oral tradition that are not recognized by most of Sentani children. Thus it is important to introduce those works to them via creative and innovative learning, i.e. using picture books and big books in Sentani and Indonesian, games, drawing as well as coloring and singing. The learning were positively responded by the children. Besides, in order they can learn at home, digital learning were also created, i.e. video and audio learning on folktales telling, how to count in Sentani language, introducing Sentani nature and environment, and folksongs sung the children. The try out proved that the children like to learn their ancestral heritages. They were able to make simple sentences, retell folktales told in Sentani, and sing understand Sentani folksongs and understand the meaning. This study concluded that folktales and folksongs can be used as interesting media media to learn Sentani language, traditional knowledge, and moral values. It is hoped that the learning can become a breakthrough of disseminating Sentani cultural heritages and various socio-cultural values embedded and as a strategy of Sentani cultural heritages preservation.

\section{Reference}

[1] Hesaraki, M.R. (2014). Literature and culture: both interaction and effectiveness. International Journal of Social Sciences, Vol 4(3), 23-25.

[2] Lethonen, Mikko (2000). Cultural Analysis of Texts. London: Sage Publications

[3] Rahman, Fathu. (2017). "The Revival of Local Fairy tales for Children Education". Theory and Practice in language Studies http:/www.academypublication. com/> DOI: ttp://dx. doi.org/10.17507/tpls.0705.02 Vol.7, No 5.

[4] Rahman, Fathu and Prihe Slamatin Lethora (2018). " Cultural Preservation: Rediscovering the Endangered Oral Tradition of Maluku (A Case Study on Kapata of Central Maluku)". Advances in Language and Literary Studies, Vol. 9 (2), pp. 91-97.

[5] Utomo, Cahyo Budi dan Ganda Febri Kurniawan(2017). "Bilamana Tradisi Lisan menjadi Media Pendidikan Ilmu Sosial di Masyarakat Gunung Pati”. Harmony Vol 2 (2), pp. 169-184

[6] Yektiningtyas, Wigati (2019) "Igniting Folktales as Children's Learning Sources in Sentani, Jayapura, Papua". Litera, Vol. 18, No. 1, pp. 105-117

[7] Yektiningtyas, Wigati and Izak Morin (2020). "Preserving Sentani Folklore to Promote Creative Economy in Jayapura, Papua". International Journal of Innovation, Creativity and Change (IJICC), Vol 14 (1), pp. 116-133 
[8] Yektiningtyas, Wigati and Monika Gultom (2018). "Exploring Sentani Folktales as Media of Teaching Local Language for Children". Sino US English Teaching Vol. 15 (5), pp. 223-235. 